\title{
Pengaruh Emotional Quotient, Pengalaman Auditor Dan Akuntabilitas Terhadap Kualitas Audit
}

\author{
Dwi Ermayanti ${ }^{*}$ \\ STIE PGRI Dewantara Jombang \\ "Korespondensi: dwi_ermayanti@yahoo.co.id \\ Diserahkan: 22 Juli 2017, Direvisis: 28 Agustus 2017 Diterima: 9 September 2017
}

\begin{abstract}
Abstrak
Penelitian ini bertujuan untuk menguji pengaruh emotional quotient, pengalaman auditor dan akuntabilitas terhadap kualitas audit. Responden dalam penelitian ini adalah auditor yang bekerja di Inspektorat Kabupaten Jombang. Penelitian ini menggunakan pendekatan kuantitatif, dengan melibatkan 24 auditor sebagai populasi sekaligus sampel. Data yang digunakan adalah data primer yang berasal dari wawancara melalui kuisioner serta data sekunder berupa bukti, catatan, atau laporan historis tentang kegiatan audit. Pengolahan data menggunakan analisa regresi berganda. Hasil analisis menunjukkan bahwa emotional quotient, Pengalaman Auditor dan akuntabilitas terhadap kualitas audit secara parsial dan bersama-sama berpengaruh signifikan terhadap kualitas audit dan variabel yang berpengaruh paling signifikan adalah Emotional Quatient
\end{abstract}

Kata kunci : emotional quotient, Pengalaman Auditor, akuntabilitas, kualitas audit

\begin{abstract}
This study aims to examine the effects of emotional quotient, auditor experience and accountability to audit quality. Respondents in this study are auditors who work in Inspectorate of Jombang Regency. This study uses a quantitative approach, involving 24 auditors as both population and sample. The data used are primary data derived from interviews through questionnaires as well as secondary data in the form of evidence, records, or historical reports on audit activities. Data processing using multiple regression analysis. The result of the analysis shows that emotional quotient, Auditor Experience and accountability to audit quality are partially and together have a significant effect on audit quality and the variables that have the most significant influence are Emotional Quatient Keywords: emotional quotient, Auditor Experience, accountability, audit quality
\end{abstract}

\section{A. PENDAHULUAN}

Prinsip-prinsip pemerintahan yang baik (good governance) telah menjadi barometer di dalam mengukur keberhasilan pengelolaan pemerintahan (Sukamulja, 2005). Dewasa ini, masyarakat juga semakin kritis mengawasi kinerja pemerintah. Semakin meningkatnya tuntutan masyarakat atas penyelenggaraan pemerintahan yang adil, bersih, transparan, dan akuntabel harus disikapi dengan serius dan sistematis. Selain itu, untuk mendorong penyelenggaraan pemerintahan perlu adanya pengawasan intern agar terwujud suatu good governance dan clean government (Arfianti, D., \& kawedar, W 2011) Pengawasan intern dapat mendukung penyelenggaraan pemerintahan yang efektif, efisien, transparan, akuntabel, serta bersih dan bebas dari praktik korupsi, kolusi, dan nepotisme (Gie, K. K. (2003).

Beberapa tahun terakhir muncul fenomena menurunnya kualitas audit (Gie, K. K. (2003). Pada beberapa kasus auditor tidak bisa menemukan kecurangan atau pelanggaran, atau justru kecurangan tersebut ditemukan oleh auditor namun tidak diungkapkan. Padahal auditor sebagai profesi independen bertanggung jawab 
mengungkapkan kecurangan atau pelanggaran tersebut. Maka agar terwujud good governance dan clean goverment, perlu adanya suatu pengawasan intern dalam penyelenggaraan pemerintah daerah sesuai dengan Peraturan Pemerintah No 20 tahun 2001 tentang Pembinaan dan Pengawasan atas Penyelenggaraan Pemerintah Daerah (Lembaga Negara Republik Indonesia Tahun 2001/Nomor 41, Tambahan Lembaran Negara Nomor 4090). Audit merupakan proses yang sistematik, independen dan terdokumentasi untuk memperoleh bukti audit dan mengevaluasinya secara objektif untuk menentukan sampai sejauh mana kriteria audit dipenuhi.

Auditor pemerintah terdiri dari Inspektorat Jenderal Departemen, Satuan Pengawas Intern (SPI) dalam lingkungan lembaga negara dan Badan Usaha Milik Negara (BUMN) / Badan Usaha Milik Daerah (BUMD), Inspektorat Wilayah Provinsi (Itwilprov), Inspektorat Wilayah Kabupaten/ Kota (Itwilkab/ Itwilkot), Badan Pengawas Keuangan dan Pembangunan (BPKP), dan Badan Pemeriksa Keuangan (BPK) sebagai lembaga pemeriksa eksternal (Mardiasmo, 2002).

Inspektorat bisa jadi ujung tombak untuk meningkatkan akuntabilitas dan transparansi dalam pengelolaan keuangan di daerah. Peran Inspektorat ini penting karena kebijakan otonomi daerah dan desentralisasi menempatkan kabupaten dan kota sebagai pelaksana terdepan dalam pembangunan. Dalam melaksanakan tugas pokok dan fungsinya, Inspektorat melaksanakan pemeriksaan rutin keseluruhan Satuan Kerja Perangkat Daerah (SKPD) yang ada pada setiap provinsi, kabupaten / kota. Inspektorat juga memiliki tugas menyelenggarakan kegiatan pengawasan umum pemda dan tugas lain yang diberikan oleh kepala daerah, sehingga dalam tugasnya Inspektorat sama dengan auditor internal. (Efendy, M, 2010) Hasil dari pemeriksaan itulah yang akan menghasilkan Laporan Hasil Pemeriksaan (LHP).

Inspektorat sebagai audit internal pemerintah haruslah berani mengungkap segala kecurangan (fraud). Apabila auditor gagal dalam mendeteksi kecurangan, maka dapat menyebabkan hilangnya kepercayaan terhadap auditor internal yang merupakan aparat pengawasan internal pemerintah yang memiliki posisi strategis dalam menegakkan pemerintahan yang bersih. Biasanya kegagalan auditor timbul karena rendahnya skeptis profesional (Noviyanti, S, 2008). Auditor internal dalam menjalankan tugas di lapangan selain mengikuti prosedur yang tertera dalam program audit, auditor harus memiliki skeptis profesional. Auditor yang skeptis tidak dengan mudahnya menerima penjelasan dari klien.

Untuk mendukung kemampuan auditor dalam mendeteksi fraud, maka auditor harus didukung oleh kompetensi dan pengalaman. Dijelaskan oleh Lastanti (2005) bahwa dengan memiliki sikap kompetensi, auditor juga dapat mengasah sensitivitas (kepekaannya) dalam menganalisis laporan keuangan yang diauditnya sehingga auditor mengetahui apakah didalam laporan keuangan tersebut, terdapat tindakan fraud atau tidak serta mampu mendeteksi trik-trik rekayasa yang dilakukan dalam melakukan fraud tersebut.

Pengalaman auditor diyakini dapat mempengaruhi tingkat skeptisme auditor. Standar Profesional Akuntan Publik (SPAP) (2012) menyatakan skeptisme profesional auditor sebagai suatu sikap yang mencakup pikiran yang selalu mempertanyakan dan melakukan evaluasi secara kritis terhadap bukti audit. Semakin banyak auditor mendapat penugasan maka auditor semakin akan lebih berpengalaman. Semakin banyak auditor berhadapan dengan temuan, maka auditor akan lebih berkompeten dalam memberikan opini. Semua petugas audit harus memelihara sikap independen, 
melaksanakan seluruh tanggungjawab profesional dengan integritas yang tinggi dan memelihara obyektifitas profesionalnya (Soekrisno, 2004).

Berbagai temuan yang harus diungkapkan yaitu mulai dari korupsi, fraud, perbuatan yang melanggar perundang-undangan atau perpajakan, perbuatan yang bisa menimbulkan kerugian finansial ataupun non finansial, dan lain-lain.

Hal-hal yang berkaitan dengan kasus di atas tentunya dapat dicegah oleh auditor yang menjunjung tinggi nilai-nilai profesionalisme. Kualitas audit merupakan probabilitas bahwa auditor akan menemukan dan melaporkan pelanggaran pada sistem akuntansi klien. Probabilitas untuk menemukan pelanggaran tergantung pada independensi auditor (Alim, M. N., Hapsari, T., \& Purwanti, L, 2007)

Inspektorat kabupaten Jombang merupakan suatu lembaga pengawasan di lingkungan pemerintahan daerah, memainkan peran yang sangat penting dan signifikan untuk kemajuan dan keberhasilan pemerintah daerah dan perangkat daerah di lingkungan pemerintahan daerah dalam menyelenggarakan pemerintahan di daerah dan mencapai tujuan dan sasaran yang telah ditetapkan. Lembaga pemerintah juga diminta untuk bisa membumi dengan masyarakat dengan memberikan pelayanan dan tata kelola pemerintahan yang baik serta CSR yang terbukti memberikan nilai positif dan signifikan terhadap nilai perusahaan (mutmainah, 2015). Dengan semakin meningkatnya tuntutan masyarakat atas penyelenggaraan pemerintahan yang bersih, adil, transparan, dan akuntabel harus di sikapi dengan serius dan sistematis. Segenap jajaran penyelenggara negara, baik dalam tataran eksekutif, legislatif, dan yudikatif harus memiliki komitmen bersama untuk menegakkan good governance dan clean government. Bermacam-macam pelanggaran yang ditangani Inspektorat Kabupaten Jombang. Mulai dari tindak disiplin, pelanggaran etika, penyelewengan anggaran dana, sampai terjerat kasus pidana. Dan salah satu kasus yang ditangani Inspektorat Kabupaten Jombang adalah penggelembungan biaya cetak stiker parkir berlangganan, sehingga merugikan negara Rp 93.000 .000 (http://surabaya.tribunnews.com, 2014)

Berdasrkan latar belakang yang telah disampaikan diatas, maka rumusan masalah yang diangkat dalam penelitian ini adalah: 1) Berapa besar pengaruh emotional quotient terhadap kualitas audit, 2) Berapa besar pengaruh pengalaman auditor terhadap kualitas audit dan 3) Apakah akuntabilitas berpengaruh signifikan terhadap kualitas audit.

Diharapkan, hasil dari penelitian ini dapat bermanfaat bagi banyak pihak, terutama pihak inspektorat kabupaten Jombang.

\section{B. Tinjauan Pustaka}

\section{Emotional Quotient (EQ)}

Menurut Goleman dalam Surya dan Hananto (2004) mengatakan bahwa koordinasi suasan hati adalah inti dari hubungan sosial yang baik. Apabila seseorang pandai menyesuaikan diri dengan suasana hati individu yang lain atau dapat berempati, orang tersebut akan memiliki tingkat emosionalitas yang baik dan akan lebih mudah menyesuaikan diri dalam pergaulan sosial serta lingkungannya. Lebih lanjut Goleman mengatakan bahwa kecerdasan emosional adalah kemapuan yang lebih dimiliki seseorang dalam memotivasi diri, ketahanan dalam menghadapi kegagalan, mengendalikan emosi dan menunda kepuasan, serta mengatur keadaan jiwa. Dengan kecerdasan emosional tersebut seseorang dapat menempatkan emosinya pada porsi yang tepat, memilah kepuasan dan mengatur suasana hati.

Sementara menurut Cooper dan Sawaf dalam Surya dan Hananto (2004) mengatakan bahwa kecerdasan emosional adalah kemampuan merasakan, memahami, dan secara 
selektif menerapkan daya dan kepekaan emosi sebagai sumber energi dan pengaruh yang manusiawi. Kecerdasan emosi menuntut penilikan perasaan, untuk belajar mengakui, menghargai perasaan pada diri dan orang lain serta menanggapinya dengan tepat, menerapkan secara efektif energi emosi dalam kehidupan sehari-hari

Kecerdasan emosi mencakup kemampuan-kemampuan yang berbeda, tetapi saling melengkapi dengan kecerdasan akademik murni (academic intelligence) yaitu kemampuan-kemampuan kognitif murni yang diukur dengan IQ. Garis pembagi utama kecakapan - kecakapan yang dimiliki seseorang terletak antara pikiran dan hati, atau secara lebih teknis, antara kognisi dan emosi.

Sebagian kecakapan bersifat murni kognitif, seperti penalaran analitis atau keahlian teknis. Sedangkan keahlian lain merupakan perpaduan antara pikiran dan perasaan, inilah yang disebut kecakapan emosi (Goleman dalam Ati, 2010). Melalui kemampuan ini seorang auditor akan mampu mengenal siapa dirinya, memotivasi dirinya, berempati pada lingkungan sekitarnya dan memiliki keterampilan sosial yang akan meningkatkan kualitasnya sebagai auditor. Ati (2010) menyatakan bahwa dalam kehidupan karir sebagai auditor, kecerdasan emosional juga mempunyai peranan besar. Untuk menjadi auditor, dibutuhkan proses yang panjang, usaha yang keras, tanggung jawab dan dukungan dari berbagai pihak. Seorang auditor diharapkan memiliki kompetensi dalam kualitas pekerjaan, kejujuran, kepercayaan diri, keyakinan hati, kontrol diri dan emosi, inisiatif, inovasi, sikap, kerja sama, keandalan, pengetahuan tentang pekerjaan, tanggung jawab, optimisme, komunikasi, orientasi pelayanan, dan pemanfaatan waktu yang baik. Sehingga aplikasi kecerdasan emosional yang tinggi atau positif dalam dunia kerja dapat membuat seorang auditor mampu menempatkan emosinya pada porsi yang tepat pada saat berinteraksi dengan rekan kerja dan kliennya

Peran Emotional quotient (EQ) bukan didasarkan pada kepintaran individu, tapi karakteristik pribadi. Memiliki kecerdasan emosional berarti memiliki kemampuan mengelola perasaannya, kemampuan memotivasi diri, kesanggupan untuk tegar dalam menghadapi stres atau frustasi, kesanggupan mengendalikan dorongan dan menunda kepuasan sesaat, mengatur suasana hati yang reaktif, serta mampu berempati dan bekerja sama dengan orang lain. Emotional quotient (EQ) merupakan syarat dalam meraih kesuksesan pribadi. Penting bagi seseorang untuk memahami apa yang diperlukan dalam membantu membangun kehidupan positif, tentunya ini bisa mendorong tercapainya tujuan-tujuan profesional..

\section{Pengalaman Auditor}

Knoers dan Haditono (1999) dalam Asih (2006 : 12) mengatakan bahwa pengalaman merupakan suatu proses pembelajaran dan penambahan perkembangan potensi bertingkah laku baik dari pendidikan formal maupun non formal atau bisa juga diartikan sebagai suatu proses yang membawa seseorang kepada suatu pola tingkah laku yang lebih tinggi. Variabel pengalaman akan diukur dengan menggunakan indikator lamanya bekerja, frekuensi pekerjaan pemeriksaan yang telah dilakukan, dan banyaknya pelatihan yang telah diikutinya.

M. Nizarul Alim et.al (2007) memberikan bukti empiris bahwa auditor berpengalaman lebih banyak menemukan item-item yang tidak umum (typical) dibandingkan auditor yang kurang berpengalaman, tetapi antara auditor yang berpengalaman dengan yang kurang berpengalaman tidak berbeda dalam menemukan item-item yang umum (typical). Menurut Suraida (2005) pengalaman auditor dalam melakukan audit laporan keuangan baik dari segi lamanya waktu maupun banyaknya penugasan. 


\section{Akuntabiltas}

Istilah akuntablitas berasal dari istilah dalam bahasa Inggris accountability yang berarti pertanggungjawaban atau keadaan untuk dipertanggungjawabkan atau keadaan untuk diminta pertanggungjawaban. Diani dan Ria (2007) mendefinisikan akuntabilitas sebagai bentuk dorongan psikologi yang membuat seseorang berusaha mempertanggungjawabkan semua tindakan dan keputusan yang diambil kepada lingkungan. Dalam sektor publik, akuntabilitas dapat diartikan sebagai bentuk kewajiban mempertanggungjawabkan keberhasilan atau kegagalan pelaksanaan misi organisasi dalam mencapai tujuan dan sasaran yang telah ditetapkan sebelumnya melalui suatu media pertanggungjawaban yang dilaksanakan secara periodik.

Libby dan Luft (1993), Cloyd (1997), dan Tan dan Aliso (1999) melihat terdapat tiga indikator yang dapat digunakan untuk mengukur akuntabilitas individu. Pertama, seberapa besar motivasi mereka untuk menyesuaikan pekerjaan tersebut. Motivasi secara umum adalah keadaan dalam diri seseorang yang mendorong keinginan individu untuk melakukan kegiatan-kegiatan tertentu untuk mencapai tujuan. Menurut Libby dan Luft (1993) dimana kaitannya dengan akuntabilitas seseorang, orang dengan akuntabilitas tinggi juga memiliki motivasi tinggi dalam mengerjakan sesuatu. Kedua, seberapa besar usaha (daya pikir) yang diberikan untuk menyelesaikan suatu pekerjaan. Orang dengan akuntabilitas tinggi dapat mencurahkan usaha (daya pikir) yang lebih besar dibanding orang yang akuntabilitas rendah ketika menyelesaikan pekerjaan (Cloyd, 1997). Ketiga, seberapa yakin mereka bahwa pekerjaan mereka akan diperiksa oleh atasan. Keyakinan bahwa sebuah pekerjaan akan diperiksa atau dinilai orang lain dapat meningkatkan keinginan dan usaha seseorang untuk menghasilkan pekerjaan yang lebih berkualitas. Menurut Tan dan Alison (1999), seseorang dengan akuntanbilitas tinggi memiliki keyakinan yang lebih tinggi bahwa pekerjaan mereka akan diperiksa oleh supervisor atau pimpinan dibandingkan dengan seseorang yang memiliki akuntabilitas rendah.

Akuntabilitas punya pengaruh yang sangat besar sebagai pengawasan demokratis, penajaman integritas dalam pemerintahan publik, meningkatkan kinerja, penajaman legitimasi pemerintahan publik, dan dapat membantu menyediakan catharsis pada publik.

Tabel 1: Dampak Akuntabilitas

\begin{tabular}{ll}
\hline \multicolumn{1}{c}{ Fungsi } & \multicolumn{1}{c}{ Disfungsi } \\
\hline Pengawasan demokratis & Terobsesi pada aturan \\
Integritas & Terlalu prosedural \\
Peningkatan & Rigiditas \\
Legimitasi & Harapan yang berlebih \\
Catharsis & Scapegoat \\
\hline
\end{tabular}

Sumber : http://teguh-kurniawan.web.ugm.ac.id

\section{Kualitas Audit}

Kualitas audit menurut Arens, Elder, \& M. (2011) adalah sebagai berikut: "Audit quality means how tell an audit detects an report material misstatement in financial statement. The detection aspect is a reflection of auditor competence, while reporting is a reflection of ethic or auditor integrity, particulary independence" .

Berdasarkan Standar Profesi Akuntan Publik (SPAP) audit yang dilaksanakan oleh seorang auditor dapat dikatakan berkualitas jika memenuhi ketentuan atau standar auditing yang berlaku umum (generally accepted auditing standards = GAAS) dan 
standar pengendalian mutu. Standar auditing tersebut menjadi acuan auditor dalam memenuhi tanggung jawab profesionalnya dalam melaksanakan audit atas laporan keuangan (Ikatan Akuntan Indonesia, 2011).

Kualitas audit yang dihasilkan dinilai dari seberapa banyak auditor memberikan respon yang benar dari setiap pekerjaan audit yang diselesaikan. Kualitas audit juga bisa dilihat dari kualitas keputusan yang diambil. Kualitas audit merupakan suatu hasil kerja auditor dalam mengevaluasi tentang kewajaran pada laporan keuangan klien dan melaporkanya. Auditor harus memiliki kualitas audit yang memadai sehingga dapat mengurangi ketidakselarasan yang terjadi antara manajemen dengan pemegang saham karena pengguna laporan terutama pemegang saham akan mengambil keputusan berdasarkan pada laporan yang telah diaudit oleh auditor.

Maka berdasarkan tinjauan pustaka diatas, hipotesis yang diangkat dalam penelitian ini adalah:

$\mathrm{Ha}_{1}$ : Emotional quotient berpengaruh signifikan terhadap kualitas audit

$\mathrm{Ha}_{2}$ : Pengalaman Auditor berpengaruh signifikan terhadap kualitas audit

$\mathrm{Ha}_{3}$ : Akuntabilitas berpengaruh signifikan terhadap kualitas audit

\section{METODE PENELITIAN \\ Rancangan Penelitian}

Penelitian yang dilakukan di inspektorat Jombang ini menggunakan pendekatan kuantitatif. Pengujian mengenai pengaruh emotional quotient (EQ), Pengalaman auditor dan akuntabilitas terhadap kualitas audit sebagai probabilitas ini dilakukan dengan menggunakan analisis regresi berganda. Dari hasil pengujian tersebut akan dijadikan dasar untuk membuat kesimpulan. Kesimpulan disusun sesuai masalah penelitian dan hipotesis.

\section{Populasi dan Sampel}

Populasi merupakan jumlah keseluruhan objek (satuan-satuan atau individuindividu) yang karakteristiknya hendak diduga (Djarwanto, P. S. (2000). Penelitian ini dilakukan di Inspektorat Kabupaten Jombang. Populasi sekaligus sampel penelitian ini adalah seluruh auditor yang bekerja di Inspektorat Kabupaten Jombang sebanyak 24 (dua puluh empat) orang

\section{Definisi Operasional dan Pengukuran Variabel}

Tabel 2: Operasionalisasi Variabel Penelitian

\begin{tabular}{|c|c|c|c|c|}
\hline Variabel & Sub Variabel & Indikator & $\begin{array}{c}\text { Nomor } \\
\text { Pertanyaan }\end{array}$ & $\begin{array}{c}\text { Skala } \\
\text { Pengukuran }\end{array}$ \\
\hline \multirow{11}{*}{$\begin{array}{c}\text { Emotional } \\
\text { quotient } \\
\left(\mathrm{X}_{1}\right)\end{array}$} & Kesadaran diri & - Kesadaran emosi & 1 & Skala Interval \\
\hline & & - Penilaian diri & 2 & \\
\hline & & - Percaya diri & 3 & \\
\hline & Motivasi & - Dorongan prestasi kerja & 4 & \\
\hline & & - Inisiatif & 5 & \\
\hline & & - Optimis & 6 & \\
\hline & Empati & - Memahami & 7 & \\
\hline & Pengendalian diri & - Kepercayaan & 8 & \\
\hline & & - Pemuasan & 9 & \\
\hline & & - Adaptabilitas & 10 & \\
\hline & $\begin{array}{l}\text { Keterampilan } \\
\text { sosial }\end{array}$ & - Mampu berorganisasi & 11 & \\
\hline $\begin{array}{c}\text { Pengalaman } \\
\text { Audit }\end{array}$ & $\begin{array}{l}\text { Pengalaman } \\
\text { auditor dalam } \\
\text { bidang audit }\end{array}$ & $\begin{array}{l}\text { - Jangka waktu menekuni } \\
\text { bidang audit } \\
\text { - Banyaknya penugasan } \\
\text { yang pernah ditugasi }\end{array}$ & $\begin{array}{l}12 \\
13 \\
14 \\
15\end{array}$ & Skala Interval \\
\hline
\end{tabular}




\begin{tabular}{|c|c|c|c|c|}
\hline & & & $\begin{array}{l}16 \\
17 \\
18\end{array}$ & \\
\hline \multirow[t]{2}{*}{$\begin{array}{c}\text { Akuntabilitas } \\
\left(\mathrm{X}_{3}\right)\end{array}$} & Motivasi & $\begin{array}{l}\text { - Motivasi dalam } \\
\text { menyelesaikan pekerjaan } \\
\text { - Bertanggungjawab dalam } \\
\text { setiap tindakan yang } \\
\text { diambil }\end{array}$ & $\begin{array}{l}19 \\
20\end{array}$ & Skala Interval \\
\hline & $\begin{array}{l}\text { Kemampuan } \\
\text { berpikir }\end{array}$ & $\begin{array}{l}\text { - Berpikir objektif dan } \\
\text { mengambil keputusan } \\
\text { dengan analisa yang baik } \\
\text { - Fokus pada fakta-fakta } \\
\text { yang relevan } \\
\text { - Berpikir secara cepat dan } \\
\text { terperinci } \\
\text { - Memakai kemampuan } \\
\text { profesionalnya dengan } \\
\text { cermat dan seksama }\end{array}$ & $\begin{array}{c}21,23 \\
22 \\
24 \\
25,26\end{array}$ & \\
\hline $\begin{array}{l}\text { Kualitas audit } \\
\text { (Y) }\end{array}$ & $\begin{array}{l}\text { Kompleksitas } \\
\text { tugas }\end{array}$ & $\begin{array}{l}\text { - Keterbukaan } \\
\text { - Konsisten berpikir dan } \\
\text { cermat } \\
\text { - Kesabaran yang tinggi } \\
\text { - Pemahaman terhadap } \\
\text { tugas }\end{array}$ & $\begin{array}{c}27 \\
28,30 \\
29 \\
31,32\end{array}$ & Skala Interval \\
\hline
\end{tabular}

Sumber : Diolah dari berbagai referensi

\section{Jenis Data dan sumber data}

Penelitian ini merupakan penelitian kausalitas yaitu yang bertujuan untuk mengetahui pengaruh antara dua ataupun lebih variabel independen terhadap variabel dependen. Pada penelitian ini, jenis data yang digunakan yaitu terdiri dari data kualitatif dan kuantitatif. Data kualitatif merupakan data yang tidak berupa angka, tetapi berupa kalimat atau gambar. Sedangkan data kuantitatif yaitu data yang berupa angka-angka data kualitatif yang diangkakan, ini didapat dari skor kuesioner yang diberikan kepada responden.

Sumber Data dalam penelitian ini adalah data primer dan data sekunder. Data primer diperoleh melalui melalui tiga metode antara lain: wawancara secara langsung dengan Kepala Inspektorat Kabupaten Jombang, survei yang berhubungan dengan Inspektorat Kabupaten Jombang, dan penyebaran kuesioner kepada auditor Inspektorat Kabupaten Jombang. Data sekunder diperoleh dengan mengumpulkan data melalui penelitian kepustakaan seperti jurnal yang berhubungan dengan auditor (Jurnal Riset Penelitian Nasional dan Internasional) serta melalui terbitan yang dikeluarkan Inspektorat Kabupaten Jombang, yang disusun selama rentang waktu 5 (lima) tahun yang berisi rencana strategis Inspektorat Kabupaten Jombang.

\section{HASIL PENELITIAN DAN PEMBAHASAN Uji Hipotesis}

Pengujian hipotesis dilakukan dengan menggunakan model analisis regresi berganda (multiple regression analysis). Dari perhitungan SPSS dapat diketahui masing-masing konstanta ( $\left.\beta_{0}\right)$ dan koefisien prediktor $\left(\beta_{1}, \beta_{2}, \beta_{3}\right)$ seperti yang disajikan pada tabel 3 berikut :

Tabel 3: Regresi Linier Berganda

Variables Entered/Removed




\begin{tabular}{|c|c|c|c|}
\hline Model & Variables Entered & $\begin{array}{l}\text { Variables } \\
\text { Removed }\end{array}$ & Method \\
\hline 1 & $\begin{array}{l}\text { Akuntabilitas, } \\
\text { Pengalaman Auditor } \\
\text { Emotional Quotient, }^{\text {a }}\end{array}$ & . & Enter \\
\hline
\end{tabular}

a. All requested variables entered.

Sumber: Data primer diolah, 2016

Tabel 4: Coefficients ${ }^{\mathrm{a}}$

\begin{tabular}{|c|c|c|c|c|}
\hline \multicolumn{5}{|c|}{ Coefficients $^{\mathrm{a}}$} \\
\hline \multirow{2}{*}{ Model } & & \multicolumn{2}{|c|}{ Unstandardized Coefficients } & \multirow{2}{*}{$\begin{array}{c}\begin{array}{c}\text { Standardized } \\
\text { Coefficients }\end{array} \\
\text { Beta }\end{array}$} \\
\hline & & B & Std. Error & \\
\hline \multirow{4}{*}{1} & (Constant) & 33.452 & 6.736 & \\
\hline & Emotional Quotient & 0.653 & 0.265 & 0.254 \\
\hline & Pengalaman Auditor & -0.534 & 0.165 & -0.376 \\
\hline & Akuntabilitas & -0.562 & 0.172 & -0.543 \\
\hline
\end{tabular}

a. Dependent Variable: Kualitas Audit

Sumber : Data primer diolah, 2016

Dari tabel diatas, diperoleh persamaan regresi berganda :

$$
\begin{aligned}
& \mathrm{Y}=\beta_{0}+\beta_{1} X_{1}+\beta_{2} X_{2}+\beta_{3} X_{3} \\
& \mathrm{Y}=33,452+0,653 \mathrm{X}_{1}-0,534 \mathrm{X}_{2}-0,562 \mathrm{X}_{3}
\end{aligned}
$$

\section{Uji $\mathbf{R}^{2}$}

Dengan koefisien determinasi $\left(\mathrm{R}^{2}\right)$ dapat diketahui seberapa besar persentase pengaruh emotional quotient, pengalaman auditor dan akuntabilitas terhadap kualitas audit. Berdasarkan perhitungan diperoleh nilai koefisien Adjusted $R$ Square sebesar 0,719 , ini dapat disimpulkan bahwa emotional quotient, pengalaman auditor dan akuntabilitas mempunyai pengaruh sebesar $71,9 \%$ terhadap kualitas audit. Sisanya $28,1 \%$ dipengaruhi faktor lainnya yang tidak diteliti dalam penelitian ini. Sedangkan angka koefisien determinasi $\left(\mathrm{R}^{2}\right)$ sebesar 0,780 menunjukan bahwa pengaruh variabel independen dengan variabel dependen adalah kuat karena memiliki nilai koefisien determinasi $\left(\mathrm{R}^{2}\right)$ di atas 0,5. Standar Error of the Estimate (SEE) sebesar 1,287, semakin kecil nilai SEE akan membuat model regresi semakin tepat di dalam memprediksi variabel dependen.

Tabel 5: Nilai Koefisien Determinasi $\left(R^{2}\right)$

Model Summary

Model 


\begin{tabular}{lcccc}
\hline & R & R Square & $\begin{array}{c}\text { Adjusted R } \\
\text { Square }\end{array}$ & $\begin{array}{c}\text { Std. Error of the } \\
\text { Estimate }\end{array}$ \\
\hline 1 & $.860^{\mathrm{a}}$ & .719 & .672 & 2.129 \\
\hline $\begin{array}{l}\text { a. Predictors: (Constant), Akuntabilitas, Pengalaman Auditor, } \\
\text { Emotional Quotient }\end{array}$ & & & & \\
\hline
\end{tabular}

Sumber : Data primer yang diolah

\section{Uji t (Pengujian Secara Parsial)}

Uji t digunakan untuk menguji ada atau tidaknya pengaruh tiap variabel independen secara parsial terhadap variabel dependen yang diuji di tingkat signifikansi 0,05 . Tabel distribusi t dicari pada $\alpha=5 \%: 2=2,5 \%$ (uji 2 sisi) dengan derajat kebebasan (df) $\mathrm{n}-\mathrm{k}-1$ atau $20-3-1=16$. Dengan pengujian 2 sisi (signifikansi $=$ 0,025 ) hasil diperoleh untuk $\mathrm{t}$ tabel sebesar 2,753. Hasil uji t dapat dilihat pada tabel 5.

Tabel 6: Hasil Uji Statistik t

\begin{tabular}{|c|c|c|c|c|c|c|}
\hline \multicolumn{7}{|c|}{ Coefficients $^{a}$} \\
\hline & & \multicolumn{2}{|c|}{$\begin{array}{l}\text { Unstandardized } \\
\text { Coefficients }\end{array}$} & \multicolumn{3}{|l|}{$\begin{array}{l}\text { Standardized } \\
\text { Coefficients }\end{array}$} \\
\hline \multicolumn{2}{|c|}{ Model } & $\mathrm{B}$ & Std. Error & Beta & $\mathrm{t}$ & Sig. \\
\hline \multirow[t]{4}{*}{1} & (Constant) & 33.452 & 6.736 & & 4.115 & .000 \\
\hline & Emotional Quotient & .653 & .265 & .254 & 2.652 & .014 \\
\hline & Pengalaman Auditor & -.534 & .165 & -.376 & -2.423 & .021 \\
\hline & Akuntabilitas & -.562 & .172 & -.543 & -3.411 & .002 \\
\hline
\end{tabular}

a. Dependent Variable: Kualitas Audit

$$
\text { Sumber : Data primer yang diolah }
$$

Berdasarkan hasil uji statistik t pada tabel diatas dapat disimpulkan sebagai berikut :

1. Hasil Uji Hipotesis 1

Variabel etika profesi memiliki tingkat signifikansi 0,014 dan t hitung 2,652 > t tabel 2,119 . Ini berarti menerima $\mathrm{Ha}_{1}$, dapat dikatakan Emotional Quotient berpengaruh secara signifikan terhadap kualitas audit.

2. Hasil Uji Hipotesis 2

Variabel pengalaman auditor memiliki tingkat signifikansi 0,021 dan $\mathrm{t}$ hitung $2,423<\mathrm{t}$ tabel - 2,119. Ini berarti menerima $\mathrm{Ha}_{2}$ dan menolak $\mathrm{H}_{0}$, sehingga dapat dikatakan pengalaman auditor berpengaruh secara signifikan terhadap kualitas audit.

3. Hasil Uji Hipotesis 3

Variabel akuntabilitas memiliki tingkat signifikansi 0,002 dan t hitung 3,411<t tabel - 2,119 . Ini berarti menerima $\mathrm{Ha}_{3}$ dan menolak $\mathrm{H}_{0}$, dapat dikatakan bahwa akuntabilitas berpengaruh signifikan terhadap kualitas audit.

\section{Pengaruh Emotional Quotient (X) Terhadap Kualitas Audit (Y)}

Hasil uji hipotesis menunjukkan bahwa tingkat signifikan variabel Emotional Quotient 0,014 < 0,05, sehingga hal ini dapat disimpulkan bahwa Emotional Quotient berpengaruh secara signifikan terhadap kualitas audit. Pengaruh antara Emotional Quotient dengan kualitas audit memiliki sifat positif. Dengan demikian, kalau auditor menerapkan aturan etika dengan baik atau Emotional Quotient tinggi, maka kualitas auditnya akan cenderung meningkat. Ini disebabkan karena Emotional Quotient lebih menekankan tuntutan terhadap profesi seseorang, dimana tuntutan itu tidak saja menyangkut hal keahlian, tapi juga adanya komitmen moral : tanggung jawab, 
keseriusan, disiplin, dan integritas moral. Hal ini konsisten dengan penelitian yang dilakukan oleh Hasil ini mendukung penelitian yang dilakukan oleh Darufitri Kartikandari (2002), Suryaningrum dan Trisniwati (2003), Fanani, Hanif, dan Subroto (2007), dan Ludigdo, Triyuwono, dan Trikollah (2006), Kusuma dan Kawendar (2011) dan Istihayu Putri Buansari (2010), bahwa kecerdasan emosional itu berpengaruh positif terhadap kualitas audit.

\section{Pengaruh Pengalaman Auditor ( $\left.\mathbf{X}_{2}\right)$ Terhadap Kualitas Audit (Y)}

Hasil uji hipotesis menunjukkan bahwa tingkat signifikan variabel pengalaman Auditor 0,021 $<0,05$, jadi dapat disimpulkan bahwa pengalaman Auditor berpengaruh secara signifikan terhadap kualitas audit. Pengaruh pengalaman Auditor dengan kualitas audit mempunyai sifat negatif. Dengan demikian, apabila auditor menampilkan pengalaman Auditor dengan sebaik-baiknya, maka kualitas auditnya cenderung meningkat. Hal ini disebabkan karena pengalaman yang baik dapat mengelola kualitas kerja secara optimal, dimana seorang auditor yang memiliki pengalaman Auditor yang tinggi dalam lingkungan kerja, cenderung lebih dapat berinteraksi dengan banyak orang. Hal ini konsisten dengan penelitian yang dilakukan oleh Penelitian ini sejalan dengan Nizarudin (2013), Suraidah (2005), yang menunjukkan bahwa pengalaman audit berpengaruh secara signifikan terhadap kualitas audit. Dapat disimpulkan semakin banyak pengalaman auditor maka akan semakin meningkatkan kualitas audit.

\section{Pengaruh Akuntabilitas (X3) Terhadap Kualitas Audit (Y)}

Hasil uji hipotesis menunjukkan bahwa tingkat signifikan variabel akuntabilitas $0,004<0,05$, jadi kesimpulannya akuntabilitas berpengaruh signifikan terhadap kualitas audit. Pengaruh antara akuntabilitas dengan kualitas audit memiliki sifat yang negatif. Dengan demikian semakin besar akuntabilitas, maka semakin tinggi tingkat kualitas audit seorang auditor. Berkualitas atau tidaknya hasil audit tergantung bagaimana auditor mampu menangani pekerjaannya. Semakin kompleks dan rumit sistem kerja dan kegiatan operasional entitas, maka makin tinggi pula rasa kebertanggung-jawaban (akuntabilitas) yang harus dimiliki oleh auditor. Jika auditor sadar akan betapa besar perannya bagi masyarakat dan bagi profesinya, maka dia akan melakukan pekerjaan dengan sebaik-baiknya.

Hal ini konsisten dengan penelitian yang dilakukan oleh Berdasarkan hasil penelitian ini diketahui bahwa akuntabilitas berpengaruh positif dan signifikan terhadap kualitas audit. Hal ini mengindikasikan bahwa kualitas audit dapat dicapai apabila auditor dalam melaksanakan tugas audit selalu disertai dengan tanggungjawab, memiliki kecermatan yang tinggi dalam memeriksa laporan, mencurahkan usaha (daya pikir) dalam menyelesaikan tugas audit serta selalu berfikir seoptimal mungkin dalam mengerjakan tugas audit. Hasil penelitian ini mendukung penelitian yang dilakukan oleh Diani Mardisar dan Ria Nelly Sari (2007) bahwa kualitas audit dapat dipengaruhi oleh rasa tanggungjawab (akuntabilitas) yang dimiliki auditor dalam menyelesaikan tugas auditSalsabila dan Prayudiawan (2011), Martini (2011), dan konsisten pula dengan penelitian internasional oleh Augustine dkk (2014). Tapi tidak konsisten dengan penelitian yang dilakukan oleh Istihayu Putri Buansari (2010), dalam penelitian tersebut akuntabilitas tidak berpengaruh signifikan terhadap kualitas hasil kerja auditor internal.

\section{E. PENUTUP}

Dari penjelasan yang telah disampaikan diatas, maka bisa disimpulkan bahwa variabel Emotional Quatient, pengalaman auditor dan akuntabilitas berpengaruh terhadap kualitas audit. Tingkat koefsiein determinasi R square (R2) sebesar 71,9\% 
menunjukkan bahwa sumbangan atau kontribusi dari Emotional Quatient, pengalaman auditor dan akuntabilitas secara bersama-sama mempunyai pengaruh signifikan terhadap kualitas audit. Dari hasil uji t diketahui bahwa masing-masing variabel Emotional Quatient, pengalaman auditor dan akuntabilitas mempunyai pengaruh positif dan signifikan terhadap kualitas audit. Melihat dari hasil koefisien determinasi parsial dapat disimpulkan bahwa variabel yang mempunyai pengaruh yang dominan adalah Emotional Quatient karena mempunyai koefisien determinasi parsialnya paling besar. Hal ini mengindikasikan bahwa Emotional Quatient yang ditunjang dengan pengalaman yang dimiliki auditor merupakan dasar yang dibutuhkan seorang auditor dalam proses audit. Maka dari simpulan diatas disarankan kepada inspektorat kabupaten Jombang untuk lebih meningkatkan hasil kerja audit yang berkualitas, terutama yang terkait dengan ketaatan terhadap etika, pengelolaan emosi yang baik, dan rasa tanggungjawab yang tinggi terhadap apa yang sudah dikerjakan, guna meningkatkan hasil kerja yang semakin berkualitas. Sedangkan untuk peneliti selanjutnya disarankan menggunakan metode lain, misalnya mengamati secara langsung kinerja auditor pemerintah Kabupaten Jombang agar lebih mengetahui kinerja auditor pemerintah yang sebenarnya. Selain itu diharapkan penelitian selanjutnya dapat memperluas variabel yang akan digunakannya misalnya etika auditor dan kecerdasan spiritual. Hal ini dikarenakan auditor yang berpegang teguh pada kode etik profesinya akan mempengaruhi kualitas hasil audit yang dihasilkannya. Sedangkan untuk menunjang tugas Auditor, kecerdasan spiritual dapat membantu auditor dalam mensinergikan secara efektif kecerdasan intelektual dan kecerdasan emosionalnya

\section{DAFTAR PUSTAKA}

Agoes, Sukrisno. 2004. Auditing ( Pemeriksaan Akuntan ). Edisi Ketiga. Jakarta : Lembaga Penerbit Fakultan Ekonomi Universitas Indonesia.

Ainia Salsabila dan H. Prayudiawan. 2011. Pengaruh Akuntabilitas, Pengetahuan Audit, dan Gender Terhadap Kualitas Hasil Kerja Auditor Internal. Jurnal Telaah dan Riset Akuntansi, Vol. 4, No. 1

Alim, M. N., Hapsari, T., \& Purwanti, L. (2007). Pengaruh Kompetensi dan Independensi terhadap Kualitas Audit dengan Etika Auditor sebagai Variabel Moderasi. Simposium Nasional Akuntansi X, 26-28.

Arfianti, D., \& KAWEDAR, W. (2011). Analisis faktor-faktor yang mempengaruhi nilai informasi pelaporan keuangan pemerintah daerah (Studi pada satuan kerja perangkat daerah di kabupaten Batang) (Doctoral dissertation, Universitas Diponegoro).

Ati, Retno Dewi. 2010. Pengaruh Kecerdasan Emosional Terhadap Kualitas Audit (Studi Empiris Pada Mahasiswa PPAk Universitas Airlangga Surabaya). Skripsi. Jember: Fakultas Ekonomi Universitas Jember

Cloyd and C. Bryan. 1997. Performance in Research Task : The Joint Effect of Knowledge and Accountability. Journal of Accounting Review 72.

D. Mardisar dan Ria Nelly Sari. 2007. Pengaruh Akuntabilitas dan Pengetahuan Terhadap Kualitas Hasil Kerja Audit. Simposium Nasional Akuntansi X, Makassar.

Deis, D. R and G. A. Groux. 1992. Determinants of Audit Quality in The Public Sector. The Accounting Review. Juli. P. 426 - 476. 
Djarwanto, P. S. (2000). Metode Penelitian, Cetakan Pertama Edisi Pertama.

Efendy, M. (2010). Pengaruh Kompetensi, Independensi, dan Motivasi Terhadap Kualitas Audit Aparat Inspektorat Dalam Pengawasan Keuangan Daerah (Studi Empiris Pada Pemerintah Kota Gorontalo) (Doctoral dissertation, UNIVERSITAS DIPONEGORO).

Elder, R. J., Beasley, M. S., \& Arens, A. A. (2011). Auditing and Assurance services. Pearson Higher Ed.

Fanani, Z., Hanif, R. A., \& Subroto, B. (2007). Penagurh Struktur Audit, Konflik Peran, Ketidakjelasan Peran Terhadap Kinerja Auditor. In The 1st Accounting Conference, Faculty of Economic University Indonesia, Depok

Gie, K. K. (2003). Reformasi birokrasi dalam mengefektifkan kinerja pegawai pemerintahan. Jakarta: Bappenas.. 2003b. Report on Corruption Abolition. Kompas, 9.

Henda S. Kusuma dan H. Warsito Kawendar. 2011. Pengaruh Pelaksanaan Etika Profesi dan Kecerdasan Emosional Terhadap Pengambilan Keputusan Bagi Auditor. Jurnal Akuntansi, Semarang

Hutabarat, G. (2012). Pengaruh Pengalaman Time Budget Pressure dan Etika Auditor terhadap Kualitas Audit (The Effect Of Audit Experience Time Budget Pressure, and Auditors' Ethics On Audit Quality). Jurnal Ilmiah ESAI.

H. T. Tan dan Alison Kao. 1999. Accountability Effect on Auditor's Performance: The Influence of Knowledge, Problem Sloving Ability and Task Complexity. Journal of Accounting Research 2

Istihayu Putri Buansari. 2010. Pengaruh Akuntabilitas, Kompetensi, Independensi, Kecerdasan Emosional Terhadap Kualitas Hasil Kerja Auditor Internal. Jakarta: Universitas Islam Negeri Syarif Hidayatullah.

Kartikandari, D. (2002). Pengaruh Motivasi, Iklim Organisasi, EQ, Dan IQ Terhadap Kinerja Karyawan: Studi Kasus DPU Dan Setda Kabupaten Bantul. Jurnal Kajian Bisnis dan Manajemen. Vol. 4. No. 2. p. 41, 48.

Lastanti, H. S. (2005). Tinjauan Terhadap Kompetensi dan Independensi Akuntan Publik: Refleksi Atas Skandal Keuangan. Media Riset Akuntansi, Auditing, dan Informasi, 5(1), 85-97.

Libby and Joan Luft. 1993. Determinants of Judgment Performance in Accounting Settings: Ability, Knowledge, Motivation, and Environment. Accounting, Organizations, and Society. July.

Martini. 2011. Analisis Faktor-faktor yang Mempengaruhi Kualitas Audit. Jurnal Akuntansi.

Mardiasmo, D., \& MBA, A. (2002). Akuntansi Sektor Publik. Yoyakarta: Andi Offiset.

Mardisar, Diani dan Ria Nelly Sari. 2007. Pengaruh Akuntabilitas dan Pengetahuan terhadap Kualitas Hasil Kerja Auditor. SNA X Makassar. AUEP-11

Monks, F. J., \& Knoers, A. M. P. (1999). Psikologi Perkembangan; alih bahasa, Siti Rahayu Haditono.

Mutmainah (2015). Analisis Good Corporate Governance Terhadap Nilai Perusahaan. Eksis: Jurnal Riset Ekonomi dan Bisnis, Vol X No 2, Oktober 2015

N. Indriantoro dan Supomo, Bambang. 1999. Metodologi Penelitian Bisnis Untuk Akuntansi dan Manajemen. Yogyakarta : BPFE - UGM.

Nomor, P. P. (20). Tahun 2001 tentang Pembinaan dan Pengawasan Atas Penyelenggaraan Pemerintahan Daerah. Keputusan Presiden Republik Indonesia (Keppres) Nomor, 74. 
Nugroho, A. S. (2006). Analisis Faktor-Faktor yang Mempengaruhi Struktur Modal Perusahaan Properti yang Go-Public di Bursa Efek Jakarta untuk Periode Tahun 1994-2004 (Doctoral dissertation, Program Pascasarjana Universitas Diponegoro).

Philip E. Tetclock dan J. L. Kim. Accountability and Judgment Processes in a Personality Prediction Task. Journal of Personality and Social Psychology Vol. 52, No. 4, April : 700 - 709.

Sukamulja, S. (2005). Good Corporate Governance di Sektor Keuangan: Dampak GCG Terhadap Kinerja Perusahaan (Kasus di Bursa Efek Jakarta). Benefit: Jurnal Manajemen dan Bisnis, 8(1), 1-25.

Sunyoto, Danang. 2001. Metodologi Penelitian Ekonomi. Jakarta : PT. Buku Seru

Surya, R., \& Hananto, S. T. (2004). Pengaruh Emotional Quotient Auditor Terhadap Kinerja Auditor di Kantor Akuntan Publik, Perspektif.

Suraida, I. (2005). Uji Model Etika, Kompetensi, Pengalaman Audit dan Risiko Audit Terhadap Skeptisisme Profesional Auditor. Jurnal Akuntansi, 9, 115-129.

Siska, E., \& Nizarudin, A. (2013). Pengaruh Pengaruh Pertumbuhan Penduduk, PDRB, Ekonomi, Dan Tingkat Inflasi Terhadap Penerimaan Pajak Daerah Pada Kota Pangkalpinang Tahun 2005-2009. Journal of Accountancy FE UBB, 1(1).

Suraida, I. (2005). Uji Model Etika, Kompetensi, Pengalaman Audit dan Risiko Audit Terhadap Skeptisisme Profesional Auditor. Jurnal Akuntansi, 9, 115-129.

Tikollah, M. R., Triyuwono, I., \& Ludigdo, U. (2006). Pengaruh Kecerdasan Intelektual, Kecerdasan Emosional, dan Kecerdasan Spiritual Terhadap Sikap Etis Mahasiswa Akuntansi (Studi pada Perguruan Tinggi Negeri di Kota Makassar Provinsi Sulawesi Selatan). Simposium Nasional Akuntansi, 9, 23-26.

Trisnawati, E. I., \& Suryaningrum, S. (2003). Pengaruh Kecerdasan Emosional Terhadap Tingkat Pemahaman Akuntansi. Simposium Nasional Akuntansi VI. Surabaya. 